\title{
HIPERREALITAS RELASI DALAM SINETRON KOMEDI “TETANGGA MASA GITU?"
}

\author{
Eldo Eka Saputra \\ Departemen Sosiologi Universitas Indonesia \\ eldoekasaputra@gmail.com
}

\begin{abstract}
Emergence of non-mainstream way of women representations in soap operas, where women are constructed as an independent individual, brought an impact to the patterns of relation between men and women. If we look at Indonesian soap operas, there are not many of them that can manage to present a non-mainstream construction of female characters. The shift on women representation is associated to how the men were represented in said soap operas, therefore this is a form of the role of the media in altering gender stigma in the society. However, in the process of construction there is a new reality presented by the media through soap operas. Baudrillard established that hyperreality is a condition in which the reality that are presented by the media overtook the real world. This makes the society, as a consumer, became convinced that the new reality is a description of real life. This research is a qualitative study on a sitcom titled Tetangga Masa Gitu? with the analysis on the contents of the sinetron. Relation between men and women shown in this sitcom is based on the factors of economic ownership, resulting in hyperreality in the patterns of relation.
\end{abstract}

\begin{abstract}
Abstrak
Munculnya representasi perempuan yang tidak mainstream di dalam sinetron, dimana perempuan dikonstruksikan sebagai individu yang independen berdampak kepada pola relasi antara perempuan dan laki-laki. Apabila melihat kondisi sinetron di Indonesia, belum banyak sinetron yang berhasil menampilkan konstruksi yang tidak mainstream terhadap tokoh perempuan. Perubahan konstruksi perempuan tidak terlepas dari bagaimana konstruksi laki-laki ditampilkan di dalam sinetron tersebut sehingga hal ini merupakan salah satu bentuk peran media dalam mengubah stigma peran gender kepada masyarakat. Namun dalam proses konstruksi tersebut terdapat suatu realitas baru yang ditampilkan oleh media melalui sinetron. Baudrillard menjelaskan bahwa hiperrealitas merupakan suatu kondisi dimana realitas yang dibangun di dalam media melebihi kondisi yang sebenarnya. Hal seperti ini menjadikan masyarakat sebagai konsumen meyakini realitas baru tersebut sebagai ilustrasi dalam kehidupan nyata. Penelitian ini merupakan suatu penelitian kualitatifterhadap sinetron komedi Tetangga Masa Gitu? dengan menggunakan metode analisis isi wacana sinetron. Relasi antara laki-laki dan perempuan dalam sinetron ini ditunjukan oleh adanya faktor kepemilikan ekonomi dalam diri perempuan sehingga pola relasi yang terjadi menunjukan adanya kondisi hiperrealitas.
\end{abstract}

Keywords: Construction of Women, Patterns of Relation, Hyperreality. 


\section{PENDAHULUAN}

Konstruksi perempuan di dalam berbagai media seringkali menempatkan perempuan sebagai objek yang tidak berdaya dan berada di bawah kendali laki-laki. Menurut Zoonen (dalam Habsari et al. 2011), representasi perempuan di dalam berbagai media sering ditampilkan sebagai sosok yang berada di ruang domestik dan dikonstruksikan sebagai individu yang pasif, ragu-ragu, patuh dan sejenisnya (selanjutnya disebut konstruksi mainstream). Selain itu perempuan juga digambarkan sangat tipikal, sebagai objek seksual atau simbol seks, objek fetish, objek peneguhan pola kerja patriarki, objek pelecehan dan kekerasan, serta selalu disalahkan (Ayun, 2011). Bentuk konstruksi mainstream tersebut menjadi perdebatan panjang mengenai konstruksi perempuan yang dianggap tidak adil di dalam media.

Perkembangan media dewasa ini memberikan suatu bentuk konstruksi yang tidak mainstream terhadap perempuan. Dimulai dari masuknya Indonesia ke era reformasi, melalui UU No.40/1999 tentang Pers dan Kode Etik Jurnalistik, telah menunjukkan adanya suatu perubahan ke arah kesetaraan konstruksi terhadap perempuan (Asmono dalam Iriantara, 2008). Apabila dilihat pada era sebelumnya konstruksi perempuan ikut dipengaruhi oleh kepentingan yang bersifat politis yang berkembang pada saat itu. Di sisi lain, perubahan institusi di tengah-tengah masyarakat seperti institusi pekerjaan yang memberikan peluang yang lebih kepada perempuan dalam mendapatkan pekerjaan di dalam sektor publik. Kondisi seperti ini juga berdampak kepada perubahan di dalam institusi keluarga terutama relasi yang terjadi antara suami dan istri, dimana perempuan tidak selamanya bersifat dependen kepada laki-laki.

Tayangan-tayangan dalam berbagai media di Indonesia, seperti salah satunya sinetron yang menjadi konsumsi publik belum terlalu banyak menampilkan bagaimana sosok independen perempuan. Media melalui sinetron mulai mencoba menghadirkan suatu bentuk realitas baru, dimana bentuk ketergantungan sekarang beralih da- lam bentuk sifat dependen laki-laki kepada perempuan. Munculnya kondisi seperti ini disebabkan oleh adanya konstruksi simbol seperti simbol power yang diberikan kepada tokoh perempuan terutama di dalam rumah tangga. Media mencoba mereproduksi bentuk peran sosial baru di dalam rumah tangga dimana peran instrumental yang biasanya diperankan oleh laki-laki dapat diperankan oleh pihak perempuan. Dalam kondisi seperti ini, peran sosial yang ditampilkan oleh media tidak bersifat kaku dimana setiap individu bisa memerankan peran sosial di dalam rumah tangga tanpa harus mengikuti pola umum yang ada di tengah-tengah masyarakat.

Reproduksi bentuk peran sosial baru yang ditampilkan oleh media ini juga membentuk pola relasi baru antara perempuan sebagai istri dan laki-laki sebagai suami. Kondisi seperti ini merupakan suatu bentuk munculnya hiperrealitas yang ditampilkan oleh media melalui sinetron. Habsari et al (2011) berpendapat bahwa munculnya konstruksi perempuan yang tidak mainstream di dalam media merupakan salah satu bentuk pengukuhan ideologi patriarki. Berdasarkan hasil penelitiannya, bentuk dominasi perempuan cenderung emosional dan berujung kepada bentuk dominasi yang bersifat negatif sehingga bentuk dominasi ini bersifat semu karena tidak menghasilkan penghormatan terhadap perempuan. Menurutnya, konstruksi dominasi perempuan dalam media juga memiliki konsekuensi sosial politis yang negatif terutama bagi citra perempuan dan bentuk relasi yang terjadi antara laki-laki dan perempuan. Saya kurang setuju dengan pendapat ini karena dalam pembahasan mengenai power yang dimiliki oleh perempuan, sumber power yang dimiliki oleh perempuan tidak tergambarkan secara jelas. Di sisi lain, penggunaan kekerasan fisik sebagai bentuk perlawanan dominasi laki-laki menjadikan power yang dimiliki oleh perempuan bersifat negatif.

Kontras dengan pendapat Habsari et al, Morrison (2014) melihat konstruksi perempuan yang tidak mainstream merupakan bentuk sosialisasi media terhadap masyarakat 
tentang peran gender dan informasi bahwa terdapat banyak karakter perempuan, serta mengubah pandangan masyarakat mengenai stereotype gender yang melihat perempuan berada di bawah dominasi laki-laki. Selanjutnya, ia juga melihat fenomena ini merupakan bentuk baru feminis dalam merepresentasikan citra positif dari perempuan.

Sependapat dengan Morrison, Spiker (2012) menyatakan bahwa hal ini merupakan suatu bentuk role models kepada masyarakat luas khususnya perempuan untuk menggunakan kemampuannya dalam mencapai eksistensi di tengah-tengah masyarakat. Hal yang sama juga dijelaskan oleh Damean (dalam Morrison, 2014) bahwa fenomena ini merupakan bagian penting dari sosialisasi dan edukasi sosial dan sexual role models terhadap individu. Saya setuju dengan pendapat ini, namun penjelasan Spiker mengenai relasi perempuan sebagai istri di dalam rumah tangga masih terlihat berada di bawah kendali suami.

Kusumandari (2014) menjelaskan bahwa konstruksi perempuan yang tidak mainstream merupakan wujud dari kemampuan perempuan untuk bangkit dan berkuasa dalam mendapatkan haknya, melawan dominasi laki-laki dan mendapatkan tempat di tengah masyarakat. Selanjutnya, Husnia (2013) berpendapat bahwa munculnya konstruksi baru terhadap perempuan merupakan simbol kekuatan yang sebenarnya dimiliki oleh perempuan. Saya setuju dengan pendapat ini, media sebagai salah satu sumber informasi masa perlu memberikan pemahaman mengenai konsep gender kepada masyarakat luas sehingga akan meminimalisir bentuk stereotype gender di tengah-tengah masyarakat.

\section{METODE}

Penelitian ini merupakan penelitian kualititatif dengan sumber data visual dari sinetron komedi (Sitkom) Tetangga Masa Gitu? (selanjutnya disingkat TMG). Analisis data visual ini dilakukan dengan cara analisis isi terhadap wacana yang disampaikan melalui analisis semiotics dan conversation analysis (Marvasti, 2004). Metode semiotics digunakan untuk melihat simbol atau tanda yang direpresentasikan dalam sinetron komedi seperti melalui pakaian dan tindakan tokoh sehingga simbol-simbol tersebut dapat diinterpretasikan sebagai sebuah maknayang disampaikan melalui tokoh. Conversation analysis dilihat dari percakapan yang terjadi antar tokoh, dimana percakapan yang terjadi antar tokoh merupakan salah satu aspek penting lainnya. Makna yang disampaikan oleh tokoh melalui percakapan memperjelas tujuan dari suatu fenomena atau pesan yang ingin disampaikan. Data yang diambil dari sitkom ini adalah beberapa episode season 1 Sitkom TMG.

\section{HASIL DAN PEMBAHASAN}

\section{Media dan Hiperrealitas}

Dalam melihat munculnya konstruksi baru perempuan di dalam media, perlu melihat konstruksi laki-lakiyang ditampilkan oleh media. Dalam membahas media, Baudrillard menyatakan bahwa media mulai tidak menjadi cerminan dari realitas yang ada di tengah-tengah masyarakat. Media menampilkan suatu bentuk realitas baru dan disuguhkan lebih riil dari realitas yang sesungguhnya (Ritzer, 2011). Terdapat beberapa konsep utama yang diungkapkan oleh Baudrillard yang berhubungan dengan hiperrealitas yaitu simulasi dan simulcra. Simulasi merupakan suatu bentuk fenomena yang dibuat menjadi hal yang lebih menarik dari aslinya. Adanya simulasi yang ditampilkan oleh media dapat menjadi daya tarik bagi setiap orang yang menyaksikannya. Proses simulasi yang ditampilkan oleh media akan menuju ke simulacra dimana hal ini merupakan reproduksi objek atau peristiwa (Kellner dalam Ritzer, 2011).

Hal menarik yang dapat dilihat dalam sitkom TMG adalah bagaimana relasi yang terjadi di dalam rumah tangga Adi dan Angel. Tokoh Adi sebagai suami Angel di dalam sinetron ini dikonstruksikan sebagai seorang laki-laki yang memiliki ketergantungan kepada istrinya terutama ketergantungan finansial. Latar utama dalam sinetron ini adalah di dalam rumah sehingga Adi lebih 
sering hadir dalam ranah domestik. Adi juga diceritakan sebagai pribadi yang cenderung pasif dan lebih banyak mengerjakan hobbynya yaitu melukis.

Hal tersebut membuat Adi lebih sering diceritakan menghabiskan waktu seharian di dalam rumah. Melihat konteks dari sinetron ini terjadi pada masyarakat urban kelas menengah atas, terdapat suatu pembentukan realitas baru kepada tokoh Adi yang cenderung dikonstruksikan tidak seperti masyarakat urban pada umumnya. Di sisi lain, interaksi dan dinamika yang terjadi di dalam rumah tangga tokoh dalam sinetron komedi ini diceritakan seakan-akan menjadi sebuah realitas yang benar-benar terjadi di tengah-tengah masyarakat.

\section{Konstruksi Gender Dalam Sinetron}

Pembahasan mengenai konsep relasi perempuandanlaki-lakididalammedia, tentu tidak terlepas dari pembahasan mengenai konsep gender yang ditampilkan oleh media. Konstruksi perempuan yang mainstream tentu tidak terlepas dari pandangan ideologi patriarki yang membagi bentuk relasi perempuan dan laki-laki ke dalam suatu konstruksi feminin dan maskulin. Konsep feminin yang sering diasosiasikan kepada diri perempuan digambarkan melalui sifat lembut, penuh afeksi, dan lemah, sedangkan konsep maskulin yang diasosiasikan kepada laki-laki dilihat dengan adanya kemampuan dalammendominasi perempuan(Handayani, 2003).

Pemahaman mengenai konsep gender inilahyang terkadang mendorong munculnya konstruksi bahwa laki-laki memiliki kendali atas perempuan di dalam penayangan berbagai sinetron. Adanya kondisi marginalisasi terhadap tokoh perempuan, tentu menjadi sumber perdebatan mengenai tidak setaranya konstruksi antara laki-laki dan perempuan. Namun, bukan hal yang mustahil terjadi dalam penayangan sinetron kondisi seperti yang telah dijelaskan di atas berubah, dimana dalam hal ini perempuan tidak lagi diposisikan dalam kondisi yang marginal bahkan mampu mendapatkan posisi yang lebih dari tokoh laki-laki.

Di sisi lain, kecenderungannya konsep maskulinitas yang selalu diasosiasikan kepada laki-laki selalu ditampilkan media melalui tampilan fisik seperti tangguh dan perkasa yang dianggap merupakan tampilan ideal bagi seorang laki-laki. Tampilan fisik tersebut ikut membentuk pendapat publik mengenai konsep gender yang ditampilkan oleh media. Dalam konteks ini, tentu harus dibahas kembali bahwa konsep gender bukanlah suatu hal yang bersifat alamiah seperti jenis kelamin, namun konsep ini dimaknai berdasakan konstruksi masyarakat yang dipengaruhi oleh latar budaya dan lingkungan.

Mencermati pemahaman ini, bukan hal yang mustahil terjadi apabila sifat-sifat maskulinitas yang dipahami dan ditampilkan oleh media terutama dalam sinetron selama ini tidak selamanya diasosiasikan kepada tokoh laki-laki. Sifat-sifat maskulinitas yang dipahami selama ini bisa saja dimiliki oleh tokoh perempuan melalui konstruksi yang ditampilkan oleh media terutama di dalam tayangan sebuah sinetron.

\section{Sinetron Komedi Tetangga Masa Gitu?}

Menurut situs resmi Netmedia, sitkom TMG merupakan salah satu sinetron Komedi dengan waktu tayang 30 menit yang menceritakan kehidupan sehari-hari dua pasangan suami dan istri. Pasangan pertama telah menikah sepuluh tahun sedangkan pasangan kedua dikisahkan sebagai sepasang suami dan istri yang baru aja menikah. Cerita sinetron membahas tentang kehidupan sehari-hari kedua pasangan dengan nuansa romantis pasangan kedua dan nuansa realistis dari pasangan pertama (Netmedia. co.id, 2015).

Sinetron ini memuat bagaimana relasi gender yang terjadi di dalam rumah tangga pasangan pertama Angel (yang diperankan oleh Sophia Latjuba) dan Adi (yang diperankan oleh Dwi Sasono) serta pasangan kedua Bintang (yang diperankan oleh Chelsea Islan) dan Bastian (yang diperankan oleh Deva Mahenra). Dalam ceritanya, 
Angel merupakan seorang lulusan sarjana Hukum yang bekerja sebagai pengacara, Adi merupakan seorang pelukis dan guru seni di SMA. Kemudian, Bastian merupakan seorang karyawan event organizer dan Bintang memiliki bisnis online.

\section{Tokoh Perempuan dalam Sitkom Tetangga Masa Gitu?}

Dalam sinetron komedi TMG, konstruksi perempuan mengalami perubahan dimana perempuan tidak dikonstruksikan secara mainstream. Dalam sinetron ini, terdapat dua tokoh utama perempuan yaitu Angel dan Bintang. Tokoh Angel dikonstruksikan sebagai tokoh yang tegas dan memiliki penghasilan melebihi penghasilan suaminya bahkan menjadi pencari nafkah utama di dalam rumah tangga. Secara finansial Angel tidak memiliki ketergantungan kepada suaminya bahkan sebaliknya suaminya yang memiliki ketergantungan secara finansial kepada Angel. Dengan adanya kondisi seperti ini, Angel memiliki power di dalam rumah tangganya dimana Angel memiliki kemampuan dalam menentukan keputusan di dalam keluarga. Selain itu, tokoh Angel juga merupakan tokoh perempuan yang sibuk dengan pekerjaannya yang terlihat dari kondisi di dalam cerita setiap episodenya dimana Angel berangkat kerja pada pagi hari dan pulang pada malam hari.

Selanjutnya tokoh Bintang diceritakan sebagai perempuan cerdas yang memiliki pengetahuan yang luas. Hal tersebut terlihat dari kemampuan Bintang dalam menjawab berbagai permasalahan dan mampu menjelaskannya secara ilmiah kepada tokoh lainnya. Selain itu, meskipun tidak bekerja di luarrumah, tokoh Bintangdiceritakan sebagai tokoh yang memiliki bisnis online sehingga penghasilan yang didapatkannya dari bisnis tersebut ikut membantu permasalahan finansial yang dihadapi bersama suaminya.

\section{Peran Dalam Rumah Tangga}

Dalam pandangan keluarga konvensional, pembagian tugas masih bersifat conjugal role-relationship dimana terdapat pemisahan peran berdasarkan jenis kelamin yang memisahkan peran perempuan sebagai seorang istri dan peran laki-laki sebagai seorang suami. Peran instrumental yang berhubungan dengan pekerjaan untuk mendapatkan nafkah yang bertujuan untuk pemenuhan kebutuhan keluarga diposisikan kepada peran laki-laki di dalam rumah tangga. Perempuan mendapatkan peran yang memposisikannya berada pada ranah domestik untuk mengurus semua urusan rumah tangga. Namun, apabila terjadi perubahan peran di dalam rumah tangga tentu akan berdampak kepada perubahan relasi antara perempuan dan lakilaki. Salah satu perubahan yang terjadi bisa dilihat pada peran instrumental yang sekarang beralih kepada perempuan sebagai pencari nafkah utama di dalam keluarga.

Dinamika relasi antara tokoh Adi dan Angel dalam sinetron komedi dimulai dari perubahan peran berbasis gender di dalam rumah tangga pasangan ini. Terjadinya perubahan peran ini berdampak kepada bagaimana interaksi kedua tokoh ini dalam menghadapi setiap permasalahan yang terjadi di dalam kehidupan mereka berdua. Beberapa adegan yang sangat memperlihatkan bagaimana terjadinya perubahan peran ini bisa dilihat pada episode "Interview Simalakama".

Suatu pagi, terjadi percakapan antara Adi dan Angel dengan latar tempat di dapur rumah mereka. Percakapan di dapur tersebut memperlihatkan bagaimana Angel dengan segala persiapannya untuk berangkat ke kantor dan telah berpakaian rapi sedangkan Adi masih menggunakan baju tidur. Adegan ini memperlihatkan bagaimana peran perempuanyang memiliki kesempatan untuk bekerja di luar rumah dan laki-laki tidak selamanya selalu mendapatkan kesempatan untuk bekerja di luar rumah. Adegan selanjutnya menceritakan bagaimana Adi meminta uang kepada Angel untuk membeli makanan karena Adi tidak memiliki uang yang disebabkan oleh kondisi dimana Adi tidak memiliki pekerjaan. Dari percakapan yang terjadi antara Adi dan Angel terlihat bentuk relasi dimana terlepasnya perempuan dalam bentuk ketergantungan kepada pihak 
laki-laki terutama dalam kondisi finansial, sebaliknya Adi sebagai suami yang memiliki ketergantungan finansial kepada Angel istrinya.

Pada cerita selanjutnya, terlihat Angel memasuki rumah setelah bekerja di kantor sedangkan Adi sibuk melukis di rumah dan hanya menghabiskan waktu seharian di dalam rumah. Adegan ini terjadi di ruang tamu rumah Adi dan Angel disaat Angel pulang dari kantor dan memasuki rumah. Dalam adegan tersebut juga terlihat Adi yang seharian hanya di rumah dan sibuk dengan lukisannya. Dari adegan tersebut terlihat bagaimana perubahan peran yang dialami perempuan dimana perempuan mendapatkan kesempatan untuk bekerja di luar rumah, sebaliknya pada episode ini memperlihatkan bahwa laki-laki yang berada di rumah di saat perempuan mendapatkan kesempatan untuk bekerja di luar rumah.

Adegan ini memperlihatkan kondisi dimana perempuan terlepas dari kondisi yang menghambat eksistensinya karena terdomestikasi. Dalam kostum yang dikenakan oleh kedua tokoh, sangat memperlihatkan bagaimana Angel sebagai perempuan yang memiliki karier pulang kantor dengan pakaian kantor yang rapi, sebaliknya hal tersebut berbeda dengan Adi yang hanya menggunakan kostum biasa layaknya orang yang hanya menghabiskan waktu di rumah saja.

Berdasarkankonstruksiperanantaralakilakidanperempuandiatas, dapatdisimpulkan bahwa peran-peran berbasis gender di dalam pandangan keluarga konvensional dapat berubah seiring perubahan-perubahan yang terjadi di dalam keluarga yang bersangkutan. Dalam adegan ini, terlihat bagaimana representasi dari modal yang dimiliki oleh perempuan seperti pendidikan dan keahlian mampu memberikan kesempatan kepada tokoh Angel untuk mendapatkan pekerjaan yang secara penghasilan berbanding terbalik dengan kondisi suaminya. Perbedaanperbedaan seperti ini di dalam kelanjutan cerita pada episode ini menjadi pemicu terjadinya perdebatan antara kedua tokoh.

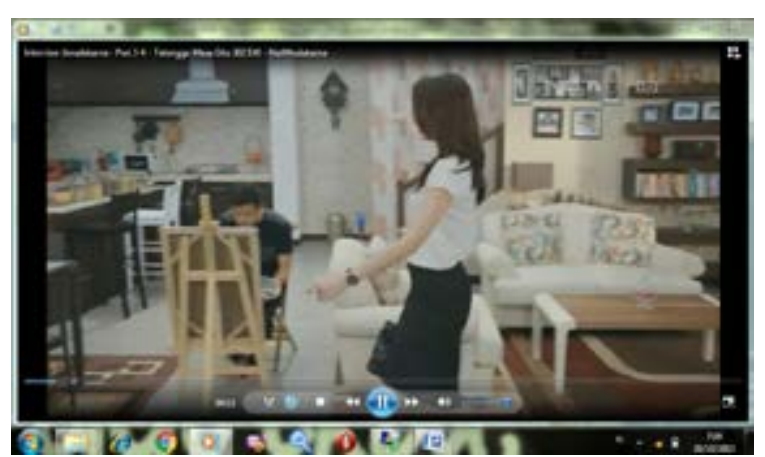

(Episode Interview Simalakama)

Gambar 1. Angel pulang dari Kantor

\section{Konstruksi Realitas}

Dalam episode "Monster Chef" diceritakan bagaimana perdebatan yang terjadi antara Adi dan Angel yang terjadi pada pagi hari, dengan latar dapur di rumah mereka. Perdebatan terjadi pada saat Adi meminta Angel untuk mempersiapkan sarapan, namun karena Angel harus berangkat untuk bekerja maka ia menyuruh Adi untuk mempersiapkan sarapannya sendiri. Selanjutnya terjadi perdebatan antara Adi dan Angel tentang peran siapa yang harusnya memasak dan siapa yang harus bekerja.

Selanjutnya pada Episode "New Job" dengan latar ruang tamu rumah Adi dan Angel yang menceritakan perdebatan antara Adi dan Angel dimana Angel memaksa Adi untuk segera mencari pekerjaan. Dalam perdebatan tersebut Angel membahas tentang pantas atau tidaknya kondisi dimana istri yang bekerja di luar rumah sedangkan suami hanya berada di rumah dan tidak bekerja.

Berdasarkan kondisi yang diceritakan dalam episode "Monster Chef' dan "New Job" terlihat bagaimana perdebatan yang terjadi di dalam rumah tangga terkait dengan adanya perubahan peran apabila dilihat dalam pandangan pembagian peran secara konvensional. Dalam episode "Monster Chef", perdebatan antara Adi dan Angel yang terjadi di dapur rumah mereka masih memperlihatkan bagaimana pembagian peran berdasarkan gender yang ada dari sudut pandang Adi. 
Hal tersebutbisaditemuidaripercakapan dari keduanya dimana Adi meminta Angel untuk menyiapkan sarapan. Namun berdasarkan situasi pada adegan tersebut, Angel ditampilkan dengan pakaian yang menggambarkan ia bersiap untuk berangkat bekerja sehingga tidak memungkinkan ia untuk mempersiapkan sarapan. Lalu percakapan berlanjut dengan Angel menyuruh Adi untuk memasak sendiri dan Adi langsung membantah pernyataan Angel dengan mengatakan siapa yang seharusnya memasak.

Dari percakapan-percakapan tersebut, bisa dilihat bagaimana perbedaan pandangan yang terjadi antara Adi dan Angel, dimana Angel cenderung mendorong Adi untuk dapat melaksanakan peran-peran yang dianggapnya selama ini hanya dilakukan oleh perempuan sebagai istri. Sebaliknya keadaan seperti ini tidak bisa diterima oleh Adi karena menurutnya peran tersebut seharusnya dilakukan oleh Angel sebagai seorang istri. Namun dalam kenyataannya peran-peran berbasis gender di dalam rumah tangga Angel dan Adi telah mengalami perubahan apabila dilihat dalam pembagian tugas berdasarkan pandangan fungsional yang cenderung membedakan peran berdasarkan gender.

Dalam pandangan fungsional, yang memiliki peran instumental yaitu peran sebagai pencari nafkah dan penyambung hidup adalah peran yang dilakukan oleh laki-laki (Manullang, 1997). Pertanyaan Angel yang ditujukan kepada Adi mengenai siapa yang seharusnya mencari nafkah cukup mempertegas bahwa dalam rumah tangga Adi dan Angel yang melakukan peran instrumental atau pencari nafkah dilakukan oleh Angel sebagai seorang istri.

Kondisi di atas juga diceritakan pada episode "New Job". Dalam episode ini percakapan antara Adi dan Angel juga memperjelas bagaimana perdebatan yang terjadi terkait pembagian peran siapa yang seharusnya mencari nafkah. Berdasarkan percakapan dalam episode ini, terlihat bahwa peraninstrumentaltidakhanyadilakukanoleh pihak laki-laki saja. Dari percakapan antara kedua tokoh tersebut, terlihat bagaimana
Angel menjalani peran sebagai pencari nafkah utama yang bekerja dari pagi hingga malam, sedangkan sebaliknya Adi sebagai suami hanya berada di rumah. Berdasarkan percakapan antara tokoh Adi dan Angel ini, menggambarkan bagaimana peran dalam rumah tangga mengalami perubahan dengan adanya konstruksi perempuan yang memiliki pekerjaan sekaligus berperan sebagai pencari nafkah utama di dalam rumah tangga.

Pada episode ini juga diceritakan bagaimana pandangan yang muncul dari tokoh perempuan mengenai pembagian peran di dalam rumah tangga. Dengan latar tempat di dapur rumah Bintang, terjadi percakapan yang antara Angel dan Bintang yang membahas tentang kehidupan keluarga mereka. Beberapa kutipan percakapan yang terjadi di antara tokoh ini menjelaskan bahwa tokoh Angel merasa keadaan dimana suaminya tidak bekerja merupakan suatu permasalahan di dalam rumah tangganya, walaupun dalam kenyataannya memang hanya dia yang bekerja.

Sebaliknya, tokoh Bintang menyatakan lebih baik dia yang bekerja di luar rumah dan suaminya yang berada di rumah dengan alasan bisa bertemu suaminya kapanpun dia mau. Perbedaan pandangan dari kedua tokoh ini, pada kenyataannya berbanding terbalik dengan kondisi yang dialami oleh kedua tokoh. Angel yang menginginkan suaminya untuk bekerja di luar rumah, kenyataannya hanya berada di rumah saja dan tidak mengahasilkan penghasilan yang dapat membantu perekonomian keluarga mereka. Sebaliknya, Bintang yang berpandangan bahwa lebih baik dia yang bekerja di luar rumah pada kenyataannya hanya bekerja di rumah mengurus bisnis online yang dimilikinya.

Perbedaan pandangan diantara tokoh perempuan ini muncul karena adanya alasan rasionalitas mengenai penghasilan. Perdebatan antara Bintang dan Angel terjadi karena Angel berpendapat bahwa uang sangat penting dalam pemenuhan kebutuhan sedangkan tokoh Bintang berpendapat bahwa uang bukanlah segalanya. Pendapat tokoh Angel menjelaskan bahwa ia lebih 
mengutamakan rasionalitas terutama pentingnya fungsi uang, karena sebagai pencari nafkah utama. Angel tentu merasakan bagaimana pentingnya uang dalam pemenuhan kebutuhan hidupnya. Perbedaan dalam menjalankan peran di dalam rumah tangga sangat memperlihatkan perbedaan yang terjadi dalam pemikiran tokoh Angel dan Bintang.

Apabila melihat perdebatan di dalam rumah tangga Adi dan Angel, representasi modal ekonomi dan modal simbolis sangat terlihat dalam tokoh Angel. Dalam mendapatkan modal tersebut, rumah tangga merupakan suatu arena yang dimanfaatkan dalam rangka mempertahankan modal tersebut. Di dalam rumah tangga Adi dan Angel sangat terlihat ketimpangan kepemilikan modal ekonomi antara Adi dan Angel. Angel merupakan pihak yang memiliki modal ekonomi yang lebih sehingga rumah tangga merupakan arena dalam memanfaatkan modal yang dimilikinya tersebut.

Apabila merujuk kepada pengertian arena menurut Bourdieu, merupakan pasar kompetitif yang di dalamnya berbagai jenis modal (ekonomi, sosial, kultural, simbolis) dimanfaatkan. Kepemilikan modal ekonomi yang dimiliki oleh Angel ditampilkan melalui interaksi yang terjadi dengan Adi suaminya. Salah satunya adalah pembahasan mengenai jumlah penghasilan yang dihasilkan Angel setiap bulannya dan kontribusi yang mampu dilakukannya dengan kepemilikan modal ekonomi tersebut. Dalam hal yang sederhana melalui percakapan yang terjadi antara Angel dan Adi sangat memperlihatkan bagaimana pemanfaatan modal ekonomi tersebut mempengaruhi interaksi keduanya.

Salah satunya terdapat pada episode "Interview Simalakama" dimana pembahasan sederhana mengenai menu makanan mampu memperlihatkan bagaimana modal ekonomi yang tidak dimiliki oleh Adi. Dalam percakapan tersebut Adi menginginkan untuk dapat mengkonsumsi daging, Angel langsung membalas pernyataan Adi tersebut dengan pernyataan agar Adi bekerja untuk dapat memenuhi kebutuhannya tersebut.
Kepemilikan modal ekonomi ini juga dapat menghasilkan modal simbolis dimana keberadaan Angel yang memiliki pekerjaan dan penghasilan mampu memenuhi kebutuhan yang diinginkannya, sedangkan Adi yang tidak memiliki pekerjaan tidak mampu memenuhi kebutuhannya sendiri.

Representasi kepemilikan modal ekonomi yang dimiliki oleh Angel juga terlihat dari percakapan selanjutnya dalam episode ini dimana Adi meminta untuk menjadi supir pribadi Angel dan adanya bayaran dari pekerjaan yang telah dilakukan oleh Adi tersebut. Selanjutnya, pakaian yang digunakan oleh Angel dan Adi di dalam percakapan ini juga menjadi simbol dari kepemilikan modal simbolis yang dimiliki oleh Angel. Perbedaan representasi Angel yang memiliki pengahasilan yang lebih daripada Adi, secara prestise ditampilkan melalui penampilan tokoh dalam percakapan ini. Sehingga dengan adanya representasi ini, diharapkan ada sebuah penghargaan yang akan didapatkan oleh Angel.

\section{Hiperrealitas Relasi}

Dalam episode "Rayuan Pulau Kelapa" diceritakan bahwa Adi menginginkan sebuah kursi yang dapat digunakannya dalam kegiatan melukis di rumah. Namun, harga kursi tersebut terlalu mahal dengan kondisi keuangan Adi. Kondisi seperti ini mendorong Adi untuk meminta bantuan Angel istrinya untuk dapat membantu memberikan uang untuk membeli kursi yang dimaksud. Angel menolak permintaan Adi dengan alasan Adi selalu meminta barang-barang yang pada dasarnya tidak terlalu penting di dalam rumah tangga mereka.

Kemudian Adi mencari cara untuk dapat meluluhkan hati Angel untuk mau menuruti permintaannya tersebut. Atas saran yang diberikan oleh Bastian tetangganya, Adi mencoba merayu Angel dengan nyanyian. Namun, apa yang dilakukan oleh Adi ini tidak berjalan dengan harapan yang diinginkannya. Angel sedikitpun tidak luluh dengan rayuan yang dilakukan oleh Adi. Permasalahan ini kemudian dapat diselesaikan melalui 
alternatif yang dilakukan Angel, dimana Angel menemukan kursi yang diminta Adi di kantornya yang sudah tidak digunakan lagi. Kursi tersebut kemudian dibawa Angel pulang dan diberikan kepada Adi suaminya.

Bentuk relasi yang ditampilkan oleh sinetron ini dapat dikatakan merupakan suatu bentuk relasi semu yang kemudian menjadi suatu fenomena yang benar-benar terjadi di tengah-tengah masyarakat. Hal tersebut bukan berarti tidak mungkin dinilai sebagai sebuah realitas karena perbedaan kepemilikan sumber daya terutama sumber daya ekonomi diantara kedua tokoh tersebut. Apabila melihat kondisi lingkungan yang diceritakan dalam sinetron komedi ini yang merupakan masyarakat urban menegah atas, tentu kondisi seperti ini bisa dikatakan sebagai suatu realitas baru yang diangkat oleh media yang mungkin saja dapat melebihi kondisi yang sebenarnya terjadi.

Sebuah penelitian yang dilakukan oleh Anggraeni (2012) terkait dengan relasi yang terjadi antara suami dan istri dengan kondisi istri yang bekerja, dapat menjadi bahan rujukan melihat bagaimana relasi yang ditampilkan dalam sinetron ini apabila dilihat pada konteks masyarakat Indonesia. Penelitian ini menjelaskan mengenai tiga keluarga dengan perubahan peran berbasis gender di tengah-tengah keluarga.

Beberapa kondisi dari penelitian ini dapat menjelaskan bagaimana realitas yang ditampilkan di dalam sinetron komedi apabila dilihat pada kondisi masyarakat yang sesungguhnya. Keluarga pertama dalam penelitian ini merupakan keluarga dengan latar belakang suku bangsa Jawa. Dalam pengambilan keputusan, keluarga ini mengutamakan diskusi dan pengambilan keputusan secara bersama. Namun, dengan adanya pemahaman mengenai ajaran agama yang diyakini oleh keluarga ini, serta pandangan bahwa suami merupakan kepala keluarga, pemegang kontrol dalam pengambilan keputusan tetap berada di tangan suami. Dengan kata lain, suami memiliki peranan yang dominan dalam pengambilan keputusan di dalam keluarga.

Keluarga kedua dalam penelitian ini dengan latar belakang budaya yang berbeda dimana suami merupakan keturunan Jawa dan istri merupakan keturunan Skotlandia. Hasil penelitian pada keluarga ini terkait pengambilan keputusan, terdapat kondisi yang demokratis dimana kedua pihak yaitu suami dan istri memiliki kesempatan untuk menentukan pendapatnya dan pada keluarga ketiga kondisinya sama dengan keluarga pertama dimana pengambilan keputusan yang dominan berada di tangan suami sebagai kepala keluarga.

Berdasarkan hasil penelitian yang dilakukan oleh Anggraeni tersebut, dalam konteks masyarakat urban dengan kondisi istri sebagai pencari nafkah utama, relasi yang terjadi diantara suami dan istri cenderung demokratis. Salah satunya yang dapat dilihat dalam sitkom dan hasil penelitian tersebut adalah melalui pengambilan keputusan di dalam rumah tangga. Terdapat perbedaan yang mendasar antara kondisi yang ditampilkan oleh media melalui sinetron dengan kondisi yang menjadi suatu realitas di tengah masyarakat. Dalam sitkom ini terlihat jelas bahwa pemegang kendali dalam menentukan keputusan di dalam rumah tangga adalah istri.

Hasil penelitian Anggraeni juga didukung oleh pendapat Abbott (1997) yang menjelaskan bahwa ketika terjadi perubahan dimana perempuan mendapatkan kesempatan untuk bekerja dan mendapatkan bayaran, pembagian kerja dalam ranah domestik akan berubah dimana laki-laki akan ikut terlibat dalam mengerjakan pekerjaan rumah dan perempuan mendapatkan kesempatan untuk bekerja di luar rumah. Willmott dan Young (dalam Abbott, 1997) juga berpendapat bahwa kondisi tersebut akan membawa suasana demokratis di dalam rumah tangga dimana laki-laki dan perempuan akan berbagi dalam menentukan keputusan dan sumber finansial.

Berdasarkan kondisi yang terjadi di dalam rumah tangga Adi dan Angel, dapat disimpulkan bahwa Angel sebagai seorang istri memiliki dominasi dalam pengambilan keputusan di dalam rumah tangga. Tokoh Adi sebagai seorang suami harus senantiasa 
mengikuti apa yang menjadi ketentuan oleh Angel meskipun dalam beberapa kesempatan terdapat perdebatan diantara kedua tokoh ini. Relasi seperti ini tentu kontras dengan realita yang terjadi pada masyarakat Indonesia terutama dalam rumah tangga dengan kondisi perubahan peran berbasis gender. Namun, sinetron komedi ini berhasil menampilkan tokoh perempuan dengan konstruksi yang baik karena tindakan yang dilakukan oleh perempuan terutama dalam pengambilan keputusan di dalam rumah tangga diikuti dengan alasan yang logis dan mampu menjawab permasalahan yang sedang dihadapi.

Pelembagaan mengenai perbedaan gender tentu berasal dari institusi terkecil yaitu keluarga. Dalam suasana keluarga patriarki, terlihat jelas bagaimana perbedaan ini melalui adanya suatu keadaan yang diharapkan kepada anak laki-laki dan anak perempuan. Pada episode "Mertua Angel Datang" dikisahkan bagaimana Angel melakukan serangkaian persiapan sebelum kedatangan mertuanya.

Dalam episode ini, dengan latar ruang tamu rumah Bastian dan Bintang diceritakan Angel meminjam ulekan dan cobekan kepada Bintang. Alasan Angel meminjam kedua benda tersebut karena takut dikritik oleh mertuanya apabila tidak menggunakannya dalam memasak. Dalam adegan ini tersirat bagaimana peran perempuan yang ada dalam pandangan mertua Angel yang masih terpengaruhi oleh pandangan peran perempuan secara konvensional di dalam rumah tangga.

Perempuan dalam meramu bumbu dapur selalu identik menggunakan ulekan dan cobekan sehingga, kedua benda tersebut disimbolkan sebagai benda yang harus dimiliki oleh perempuan dalam memasak karena peran tersebut merupakan tanggung jawab perempuan di dalam rumah tangga. Namun, dalam kenyataannya pada adegan ini Angel tidak memiliki kedua benda tersebut karena biasanya membeli bumbu dalam kemasan sedangkan Bintang tidak lagi menggunakan benda tersebut dalam proses memasak seperti yang diungkapkan oleh Bintang kepada Angel:

"Maaf mba aku ga punya cobekan, aku biasanya ngalusin bumbu itu pake blander. Tumben mba Angel mau nyambel biasanya cukup aja pake chili sauce botol".

Dari pernyataan Bintang tersebut menjelaskan bagaimana Angel sebagai seorang perempuan karier sudah tidak lagi melakukan peran dengan tugas memasak di rumah. Semua kebutuhan dapur tersedia dengan membeli dalam bentuk kemasan. Adanya perubahan peran Angel sebagai istri yang bekerja di luar rumah ini sangat bertolak belakang dengan pandangan mertuanya mengenai peran seorang istri di dalam rumah tangga. Perbedaan pandangan dan perubahan peran inilah yang menjadikan Angel untuk berusaha menyesuaikan diri dengan apa yang ada di fikiran mertuanya tersebut.

Cerita berlanjut ke ruang tamu rumah Adi dan Angel dimana Angel meminta Adi untuk ikut mempersiapkan kedatangan Ibunya. Ketika mertua Angel datang, percakapan terjadi di meja makan antara Angel, Adi, dan Ibu (mertua Angel). Dalam percakan tersebut terdapat beberapa percakapan yang diungkapkan oleh Ibu mengenai pandangannya tentang peran istri. Dalam dialog tersebut, terlihat bagaimana pandangan pembagian peran dalam keluarga konvensional yang menganggap bahwa perempuan itu sebaiknya di rumah saja dan semua pekerjaan rumah tangga seperti membersihkan rumah dan mencuci piring adalah wewenang istri tanpa campur tangan suami.

Perubahan peran Angel yang bekerja di luar rumah menjadi bahasan Ibu mertua Angel. Dalam pandangannya, perempuan itu sebaiknya di rumah dengan peran melayani suami dan mengerjakan semua pekerjaan rumah tangga seperti yang diungkapkan oleh mertua Angel yang mempertanyakan mengapa harus bekerja di kantor dan pandangan mertuanya bahwa perempuan sebaiknya berada di rumah saja.

Perubahan peran Angel sebagai se- 
orang istri dalam pandangan mertuanya berdampak kepada kurang maksimalnya Angel dalam mengerjakan pekerjaan rumah. Ketika ibunya mengritik gelas yang ada nodanya sebagai akibat Angel bekerja di luar rumah sehingga tidak maksimal menjalankan perannya sebagai istri di dalam rumah tangga. Adi, sebagai suami berusaha melakukan pembelaan kepada Angel dengan mengatakan bahwa gelas tersebut dia yang menyuci dan pernyataan tesebut membuat ibunya bertanya dan heran mengapa suami yang melakukan pekerjaan tersebut.

Pandangan mertua Angel masih bersifat a segregated conjugal role-relationship di mana pembagian peran dan tugas di dalam rumah tangga masih berdasarkan perbedaan jenis kelamin. Pembagian ini menempatkan perempuan sebagai istri melakukan semua pekerjaan di dalam rumah tangga. Dalam kenyataannya, terjadi perubahan bentuk relasi dimana tugas di dalam rumah tangga tidak lagi dikerjakan secara terpisah. Dalam kondisi ini, Adi dan Angel menjalankan tugasnya secara bersamaan sehingga pekerjaan rumah tangga tidak hanya menjadi tanggung jawab Angel sebagai seorang istri, Adi sebagai suami juga terlibat dalam tugas tersebut. Kondisi tersebut merupakan wujud dari a joint conjugal role-relationship dimana antara suami dan istri tidak lagi terdapat pembedaan peran berdasarkan jenis kelamin dan suami istri bersama-sama melakukan tugas tanpa adanya pembedaan tersebut.

Pernyataan-pernyataan yang disampaikan oleh mertua Angel dalam episode ini, merupakan pandangan pelembagaan gender di dalam rumah tangga. Apabila dilihat kondisi rumah tangga Adi dan Angel, terdapat perubahan secara struktural di dalam rumah tangga pasangan ini. Kondisi seperti ini, seharusnya membawa keadaan yang lebih dinamis dimana apabila telah terjadi perubahan peran maka persoalan mengenai peran domestik dan peran publik bukanlah suatu keadaan yang harus dipermasalahkan. Seperti yang dijelaskan oleh Anggreni dalam penelitiannya, dimana apabila istri yang melakukan peran di ranah publik, maka suami juga akan berpartisipasi dalam melakukan pekerjaan-pekerjaan di dalam rumah. Kondisi seperti ini tentu akan membawa suasana yang lebih demokratis dimana masing-masing pihak saling membantu dalam melakukan tugasnya sehingga tidak akan ada lagi perdebatan mengenai pembagian-pembagian peran di dalam rumah tangga.

\section{Pola Relasi Dalam Rumah Tangga}

Bekerjanya power dalam interaksi suami dan istri di dalam sebuah rumah tangga akan berdampak kepada pola relasi dalam rumah tangga tersebut. Scanzoni (dalam Anggraeni, 2012) menjelaskan bahwa terdapat empat macam pola relasi dalam sebuah pernikahan terkait dengan adanya alokasi kekuasaan dan pembagian kerja di dalam rumah tangga. Pertama pola relasi tersebut adalah pola owner-property. Bentuk relasi seperti ini menunjukan bahwa istri merupakan milik suami seutuhnya. Dalam pola seperti ini, istri memiliki ketergantungan secara finansial karena terdapat pembagian kerja dimana peran instrumental yang berhubungan dengan mencari nafkah adalah tugas seorang suami. Istri dalam perannya berada pada ranah domestik, dimana istri bertugas dalam mengurus segala urusan dan pekerjaan di rumah. Terkait dengan pengambilan keputusan, suami memiliki posisi yang dominan sehingga istri harus mengikuti keputusan yang ditentukan oleh suaminya.

Pola yang kedua adalah pola headcomplement. Pada pola relasi ini, kedudukan istriadalah sebagai pelengkap bagi suaminya. Sebagai pemilik posisi yang lebih tinggi, seorangsuamimulaimemberikankesempatan kepada istrinya dalam proses pembuatan keputusan di dalam rumah tangga. Namun, ketentuan akhir dalam penentuan keputusan yang berhubungan dengan permasalahan di dalam rumah tangga tetap ditentukan oleh pihak suami. Apabila dibandingkan denga pola relasi owner-property, dalam pola relasi ini, partisipasi istri mulai meningkat terkait dengan penentuan keputusan.

Selanjutnya, pola relasi yang terdapat di dalam sebuah rumah tangga adalah pola 
relasi senior-junior partner. Perubahan yang terlihat dalam pola relasi ini adalah adanya peran istri dalam pencari nafkah tambahan di dalam rumah tangga. Relasi ini menjelaskan bahwa istri mulai berkontribusi secara ekonomi namun pencari nafkah utama tetap berada pada peran suami. Kondisi dimana istri hanyalah pencari nafkah tambahan inilah yang menjadikan posisi istri sebagai junior dan suami merupakan senior karena memiliki tanggung jawab dalam menghidupi dan memnuhi kebutuhan utama di dalam rumah tangga.

Pola yang terakhir adalah pola relasi equal partner. Dalam pola relasi ini, terdapat kesetaraan antara suami dan istri. Kesetaraan ini dapat dilihat dari segi finansial keluarga dimana masing-masing pihak memiliki peran yang sama dalam perekonomian keluarga. Selain itu, dalam pembuatan keputusan di dalam rumah tangga, masing-masing pihak juga memiliki kesempatan yang sama sehingga kondisi seperti ini menciptakan suasana demokratis dalam interaksi suami dan istri. Pola ini juga menunjukan bahwa tidak ada pihak yang mendominasi terhadap pihak lainnya. Kondisi ini memberikan kesempatan kepada setiap pihak untuk menjalankan peran-peran di dalam rumah tangga secara bersamaan sesuai kesepakatan yang telah disetujui secara bersama-sama.

Melihat relasi yang ditampilkan oleh sitkom ini, terlihat bahwa pola relasi yang terjadi di dalam rumah tangga Adi dan Angel dalam proses pengambilan keputusan dapat dikategorikan ke dalam head-complement. Namun, konstruksi yang muncul dalam relasi ini adalah suami yang berada pada posisi pelengkap. Hal tersebut dapat dilihat dari penanggung jawab utama dalam mencari nafkah utama di dalam rumah tangga adalah Angel sebagai seorang istri. Dalam proses pengambilan keputusan, terlihat perdebatan yang terjadi antara tokoh Adi sebagai seorang suami dan Angel sebagai seorang istri.

Perdebatan ini merupakan suatu kondisi dimana Adi masih mendapat kesempatan dalam menyuarakan pendapatnya terkait dengan pengambilan keputusan di dalam rumah tangganya dengan Angel. Namun, keputusan terakhir tetap ditentukan oleh Angel sebagai pemilik power di dalam rumah tangga. Salah satunya terlihat dalam episode "microwave" dimana suatu perdebatan yang terjadi diantara Adi dan Angel mengenai penggunaan salah satu alat elektronik di rumah mereka. Masing-masing pihak telah mengutarakan pendapatnya, dimana Angel berpendapat bahwa microwave yang terdapat di rumah mereka harus dimatikan dengan alasan penghematan biaya listrik.

Sebaliknya, Adi tetap teguh dengan pendiriannya bahwa alat elektronik tersebut tidak harus dimatikan karena tidak berpengaruh dengan beban biaya listrik yang harus dibayar setiap bulannya. Namun, dengan pendapat yang disampaikan oleh Angel membuat Adi harus mengikuti ketentuan tersebut dan terkesan Adi harus patuh dengan apa yang ada dalam pemikiran Angel istrinya.

Pola relasi yang terjadi di dalam rumah tangga Adi dan Angel, terkait dengan konstruksi perdebatan mengenai peran dapat dikategorikan ke dalam owner-property. Hal initerlihatjelasdalam bentuk ketergantungan dari Adi secara finansial kepada Angel. Adanya kondisi ketergantungan Adi ini memberikan suatu bentuk simbol kekuasaan terhadap Angel dalam mengatur kondisi di dalam rumah tangga bahkan Angel juga memiliki kendali dalam mengatur persoalan pribadi yang dilalui oleh Adi.

Beberapa perdebatan mengenai siapa yang membayar tagihan bulanan rumah yang terjadi antara Adi dan Angel mempertegas bahwa Angel memiliki wewenang besar dan menjadikan modal yang dimilikinya tersebut sebagai alternatif untuk dapat mempengaruhi Adi suaminya. Kondisi yang berbanding terbalik dengan Angel, membuat Adi dicitrakan sebagai individu yang tidak memiliki suatu hal yang mampu dijadikan sebagai sumber power dalam relasi yang terjadi dengan Angel istrinya.

\section{SIMPULAN}

Munculnya hiperrealitas yang ditayangkan oleh media dalam Sitkom ini ditampilkan 
melalui adanya pembentukan peran sosial yang baru di dalam rumah tangga. Peran instrumental yang biasanya diperankan oleh laki-laki sebagai seorang suami, sekarang dapat diperankan oleh seorang perempuan dengan status sebagai seorang istri. Pembentukan peran sosial baru ini berdampak kepada pola relasi antara suami dan istri, dimana dalam perubahan peran ini, status seorang istri ditampilkan seolah menjadi status seorang suami terutama dalam bentuk pengambilan keputusan di dalam rumah tangga.

Selanjutnya, perempuan sebagai seorang istri ditampilkan melalui simbolsimbol kepemilikan modal ekonomi. Dalam proses munculnya hiperrealitas, perdebatan mengenai peran-peran berbasis gender di dalam rumah tangga cukup memperjelas adanya produksi peran sosial baru di dalam sitkom ini. Di sisi lain, simbol power yang dimiliki oleh perempuan juga ditampilkan dalam relasi rumah tangga. Power yang dimaksud terkait dengan proses pengambilan keputusan dimana dominasi dalam penentuan keputusan berada di pihak perempuan.

Apabila melihat kondisi masyarakat perkotaan di Indonesia, terkait dengan adanya perubahan peran di dalam rumah tangga, pola relasi yang terbentuk antara suami dan istri masih menempatkan suami sebagai pemegang kendali di dalam rumah tangga. Hal ini terbentuk oleh adanya latar belakang pemahaman kultur yang dianut oleh individu yang bersangkutan. Adanya hiperrealitas yang ditampilkan oleh sitkom ini memberikan suatu pemahaman kepada masyarakat luas terutama mengenai peran gender yang dipahami selama ini. Selain itu, sitkom ini juga menampilkan bahwa peranperan berbasis gender di dalam rumah tangga tidak selamanya bersifat kaku, dimana setiap individu dapat memainkan peran yang tentunya berdampak kepada relasi antar individu di dalam rumah tangga tersebut.

\section{DAFTAR PUSTAKA}

Jurnal dan Skripsi:

Anggraeni, Ratih Anggun. 2012. "Pola Relasi Suami Istri Terkait dengan Pembagian Kerja dan Pengambilan Keputusan (Studi Kasus terhadap Tiga Keluarga dalam Perubahan Peran di Keluarga”. Skripsi Departemen Sosiologi Universitas Indonesia.

Ashadi, Siregar. 2004. "Ketidakadilan Konstruksi Perempuan di Film dan Televisi". Vol. 7. Jurnal Ilmu Sosial dan Ilmu Politik Universitas Gadjah Mada.

Ayun, Primada Qurrota. 2011. "Sensualitas dan Tubuh Perempuan dalam Film-Film Horor di Indonesia (Kajian Ekonomi Politik Media)". Tesis Pascasarjana Ilmu Komunikasi Gadjah Mada.

Habsari, Sri Kusumo, Fitria Akhmerti Primasita, M. Taufiq Al Makmun. "Representasi Dominasi Perempuan dalam Rumah Tangga: Feminisme atau Patriarki? (Sebuah Analisis Tekstual terhadap Situasi Komedi (Sitkom) "Suami-Suami Takut Istri)", Vol. 23. Jurnal Humaniora Universitas Gadjah Mada.

Handayani, Resna. 2003. "Kecil-Kecil Jadi Manten: Representasi Feminitas dan Maskulinitas di Sinetron Berideologi Patriarki-Kapitalis". Skripsi Fakultas Ilmu Sosial dan Ilmu Politik Universitas Indonesia.

Husnia, Tina. 2013. "The Resistance toward Patriarchal Performed by Anne Boleyn in TheOther Boleyn Girl Film by Justin Chadwick". Allusion Volume o2 Number o1 (February 2013).

Iriantara, Yosal. 2008. "Media, Gender dan Melek Media". Jurnal Universitas Islam Nusantara. Diakses 25 November 2015. (http://www.uninus.ac.id/data/data ilmiah/MEDIA,\%20GENDER,\%20 MELEK-MEDIA.pdf)

Kusumandari, Edwina. 2014. "Representasi Perlawanan Perempuan terhadap 
Ideologi Patriarki dalam Film Potiche Karya François Ozon”. Fakultas Ilmu Pengetahuan Budaya Universitas Indonesia.

Manullang,Christine.1997. “AnalisaDeskriptif Hubungan antara Stereotipe Gender dan Orientasi Karir (Studi pada Mahasiswa Mahasiswi Program Diploma III FISIP UI). Skripsi Departemen Sosiologi Universitas Indonesia.

Morrison, Danielle. 2014. "Brave: A Feminist Perspective on the Disney Princess Movie". California Polytechnic State Unversity.

Sofyadi, Rizki. 2006. "Hyperreality atas Hak Perempuan dalam Film Indonesia (Studi Analisis Wacana Kritis terhadap Film Arisan dan Pasir Berbisik". Skripsi Fakultas Ilmu Sosial dan Ilmu Politik Universitas Indonesia.
Spiker, Julia A. 2012. "Gender and Power in the Devil Wears Prada". International Journal of Business, Humanities and Technology, Vol. 2 No. 3; May 2012

Buku:

Abbot, Pamela, Claire Wallace. 199. An Introduction to Sociology (Feminist Perspective). London. Routledge. Connell, 1987. Gender and Power. Polity Press.

Ihromi, T.O. 1999. Bunga Rampai Sosiologi Keluarga. Jakarta: Yayasan Obor Indonesia.

Macionis, John J. 2008. Sociology. New Jersey: Pearson Education International.

Marvasti, Amir. B. 2004. Qualitative Research in Sociology. London: SAGE Publications.

Ritzer, George. 2011. Sociological Theory. McGrawHill. 